\title{
Endometrial responses to embryonic signals in the primate
}

\author{
PRAJNA BANERJEE ${ }^{1}$ and ASGERALLY T. FAZLEABAS*,2 \\ ${ }^{1}$ Department of Physiology and Biophysics and \\ ${ }^{2}$ Department of Obstetrics and Gynecology, University of Illinois, Chicago, IL, USA
}

\begin{abstract}
The delicate interaction between an embryo and the uterus to initiate implantation and maintain pregnancy is one of the most elegant and fascinating interactions in human biology. Understanding the molecular events of embryo-maternal interaction is of interest to reproductive biologists, clinicians and couples affected by infertility. We have established the baboon as the non-human primate model for studying embryo implantation. Infusion of chorionic gonadotropin (CG), the major embryonic signal of primates, into the uterine cavity of normal cycling baboons during the window of receptivity induces a myriad of morphological, biochemical and molecular changes in the estrogen and progesterone primed endometrium. The luminal epithelium responds by forming plaques, the overall secretory function of the glandular epithelium increases and the stromal response is characterized by induction of $\alpha$-smooth muscle actin ( $\alpha$ SMA). Cross talk between ovarian and embryonic hormones is evidenced by the fact that these responses are inhibited upon treatment with a progesterone receptor antagonist. CG signals principally through the seven transmembrane LH/CG G-protein coupled receptor, and activates a mitogen activated protein kinase pathway in the endometrial epithelium that is unique and independent of all the classical signaling pathways. In the stromal compartment, CG both rescues stromal fibroblasts from their apoptotic demise and also differentiates them into the decidualized phenotype. We propose that stromal cell survival and differentiation is mediated by a critical modulator of cell fate, Notch-1. Thus, CG is an important embryonic signal which modulates communication between the embryo and the endometrium and induces changes that are critical to successful implantation.
\end{abstract}

KEY WORDS: chorionic gonadotropin, implantation, endometrium, LH-CG receptor, decidualization

\section{Implantation}

One of the most elegant and fascinating interactions in human physiology is the one that takes place between an embryo and the uterus to initiate and maintain the process of implantation. However, the relative inefficiency of this process in human reproduction remains to a great degree, unexplained. Fecundity (the probability of conception during one menstrual cycle) is recorded at about 30 percent and over 75 percent of the failed pregnancies are attributed to implantation defects (Wilcox et al., 1999). Thus failed implantation is a major cause of failure of both normal pregnancies as well as those resulting from assisted reproductive techniques (Margalioth et al., 2006). As a result, understanding the molecular events of embryo-maternal interaction has long been of interest to reproductive biologists, clinicians and couples affected by infertility. However, it is not possible, for both practical and ethical reasons, to study the physiological process of implan- tation in women. Studies in other animal models e.g. mice and rats have distinct advantages (genetic modification, cost, maintenance) but they remain essentially limited in their ability to elucidate the physiological mechanisms of human implantation. In contrast, non-human primate models have menstrual cycles that are similar to humans and comparable hormonal profiles, making them the best possible model for comparative studies of human implantation.

Across a multitude of species ranging from the rodent to the primate, the period of time for the initiation of implantation is very

\footnotetext{
Abbreviations used in this paper: $\alpha \mathrm{SMA}, \alpha$-smooth muscle actin; $\mathrm{CG}$, chorionic gonadotropin; COX-2, cyclooxygenase-2; ECM, extracellular matrix; IGFBP1, insulin-like growth factor binding protein; LHCGR, lutenizing hormonechorionic gonadotropin receptor; MAPK, mitogen activated protein kinase; $\mathrm{PGE}_{2}$, prostaglandin $\mathrm{E}_{2}$.
} 
limited. This short window of time is aptly termed the "window of uterine receptivity". Limitations to this time period are set by the degree of maturation of the embryo, the development of the endometrial lining and a mutual signal that confirms the initiation of implantation. Broadly, the process of embryo implantation involves a coordination of two simultaneous processes: development of the newly formed embryo and the maturation of the uterine endometrium. The embryo, entering the uterine cavity a few days after fertilization, begins an intimate dialog with the endometrium in order to ensure its own survival and development. On the maternal end, upon recognizing a cycle involving conception, the endometrium, one of the most dynamic entities in the body, alters its normal course of sloughing and regeneration, and prepares itself to receive this newly formed embryo. These two processes are inseparable and successful implantation requires a precise coordination brought about by an eloquent interplay between the embryo, ovary and the endometrium.

\section{Embryonic signals}

The initial identification of a gonad stimulating substance produced by an embryo dates back to the pioneering work by Aschheim and Zondek in the 1920s (Aschheim and Zondek, 1928). These discoveries led to the establishment of the first pregnancy test for women. Subsequently, this substance was identified, purified and characterized as chorionic gonadotropin (Bahl, 1969).

Fertilization in primates, as in most species occurs in the oviduct. Around the sixth day following fertilization, the developing embryo (called a blastocyst at this stage) hatches from its shell, the zona pellucida, prior to its attachment to the uterine epithelium. Trophoblast and syncytiotrophoblast cells of the blastocyst produce various hormones and cytokines e.g. chorionic gonadotropin (CG), interleukin -1 and insulin- like growth factor II, displaying profound effects on the endometrium (Cameo et al., 2004; Fazleabas et al., 2004; Strakova et al., 2005). In primates, the first indication of the presence of a viable embryo is the detection of $C G$ in the peripheral circulation and maternal urine; this event occurs even when the blasocyst is still free-floating in the uterine cavity in its pre-implantation stage. Subunits of $C G$ are reportedly transcribed by 8-cell embryos (Bonduelle et al., 1988), and the fully functional bio -active hormone is detectable in serum and urine as early as day 9 following the lutenizing hormone (LH) surge (Lohstroh et al., 2005).

CG is a member of the glycoprotein family of hormones, which includes the pituitary hormones lutenizing hormone, follicle stimulating hormone and thyroid stimulating hormone. These hormones are heterodimers comprising a common $\alpha$ - subunit and a species specific $\beta$ - subunit. The CG $\beta$ subunit shares extensive homology with the LH $\beta$ subunit (Bo and Boime, 1992; Pierce and Parsons, 1981). Synthesis of CG occurs in distinct stages: the cytotrophoblasts produce the $\mathrm{CG} \alpha$ subunit, and following multiplication and differentiation of the cytotrophoblasts to form the syncytiotrophoblasts, the latter produce the CG $\beta$ subunit (Muyan and Boime, 1997).

Other embryonic signals include growth factors such as the epidermal growth factor, which plays a role in trophoblast differentiation and invasion (Bass et al., 1994; Dakour et al., 1999) and cytokines such as interleukin -1, which along with CG is consid- ered to be one of the earliest signals from the embryo and modulates communication between the embryo and the maternal endometrium (Simon et al., 1997; Strakova et al., 2000; Strakova et al., 2005; Vigano et al., 2003). However, in this review we shall focus on the effect of $C G$ as the primary embryonic signal and discuss the responses of the primate endometrium to $C G$.

The endometrium is a dynamic entity which, under the control of ovarian hormones - estrogen and progesterone, alters itself in a cyclic pattern between phases of proliferation, secretion, attrition and regeneration. The endometrial lining is composed of a transient superficial functional layer and a germinal or basal layer. The luminal epithelium is the first maternal surface that is encountered by the implanting embryo. In a cycle involving conception, subsequent to ovulation, a critical function of the ovary is the role played by the corpus luteum in producing progesterone which can then maintain the endometrial lining and prevent it from undergoing apoptosis. Thus, one of the vital requirements for establishing pregnancy is the rescue of the corpus luteum from its impending demise and to extend the luteal production of progesterone. For a very long time the proposed role of embryonic signals such as CG was limited to this. However, in the last decade many studies have clearly demonstrated that CG exerts both autocrine effects on the trophoblast, promoting cytotrophoblast differentiation (Shi et al., 1993) and migration of extravillous trophoblasts (Zygmunt et al., 2005), and paracrine effects on the maternal ovary and the endometrium (Filicori et al., 2005).

A valuable primate model for investigating the modulation of the endometrium during pregnancy is the baboon. Uterine receptivity in these animals can be demarcated into three distinct phases. Phase I, regulated by the ovarian hormones estrogen and progesterone, is distinguished by the presence of columnar epithelium with microvilli and an increase in stromal cell proliferation. Biochemical changes such as an increase in smooth muscle myosin and a decrease in levels of Muc1 are characteristics of this phase (Hild-Petito et al., 1996). Phase II is characterized as the 'blastocyst response phase' and features changes induced by the embryonic signals viz. CG, superimposed on the hormonally primed endometrium. The final phase, Phase III encompasses the responses following attachment and implantation, which includes decidualization of endometrial stromal cells.

In our initial studies in establishing the baboon as a nonhuman primate model for studying human implantation (Fazleabas etal., 1999), we extensively investigated the changes in Phase II of uterine receptivity. Upon infusion of CG into the oviduct of normal cycling animals in a manner that mimics blastocyst transit between days 6 and 10 postovulation, we observed dramatic morphological and biochemical changes in all of the different cellular components of the uterine endometrium. The luminal epithelium responded by forming plaques (a distinctive early maternal response to pregnancy), characterized by hypertrophy of the epithelium and rounding up of the cells to form acinar clusters (Tarara et al., 1987). The overall secretory function of the glandular epithelium was increased, with glycodelin being the major secretory product and the stromal response was characterized by induction of $\alpha$ smooth muscle actin ( $\alpha \mathrm{SMA})$. Evidence of cross talk between ovarian and embryonic hormones was established by the fact 
that the responses were inhibited upon long term treatment with a progesterone receptor antagonist (Banaszak et al., 2000).

\section{Molecular biology of the LHCGR}

CG signals principally through the same seven transmembrane G-protein coupled receptor as LH - the LH-CG receptor (LHCGR) (Mcfarland et al., 1989). In fact, CG binds with a greater affinity to the LHCGR as compared to LH. The LHCGR is an $880 \mathrm{~kb}$ gene comprising 10 introns and 11 exons. The greater part of the receptor including the entire carboxyl terminal consisting of the seven transmembrane helices, the three interconnecting extracellular and intracellular loops and the cytoplasmic tail is encoded by the $11^{\text {th }}$ exon. The first ten exons only comprise the extracellular N-terminal exodomain consisting of numerous leucine-rich repeats involved in protein-protein interactions.

The LHCGR is shown to be present and to play diverse roles in various tissues of reproductive (gonadal and extra-gonadal) and non-reproductive origin (Apaja et al., 2005; Pakarainen et al., 2007; Segaloff and Ascoli, 1993). Studies both in vivo(Fazleabas et al., 1999) and in vitro (Zhou et al., 1999) have also confirmed that the LHCGR receptor is present in the baboon and human endometrium. These studies have also demonstrated that this receptor is functional and regulates biological processes related to implantation. Although much work has been done to understand the regulation and expression of the LHCGR in the endometrium, a large number of questions still remain unanswered. For example, in the human, the full-length LHCGR is expressed in the endometrium during both the proliferative and secretory phases of the cycle (Reshef et al., 1990). However, during early pregnancy, the decidua expresses only a truncated form of the receptor (Licht et al., 2003). In the baboon, we have shown that the LHCGR was absent in the endometrium during the proliferative phase, while in the secretory phase, both the luminal and the glandular epithelial cells expressed the receptor. With the onset of pregnancy, the expression of the LHCGR was limited to the stromal cells surrounding the spiral arteries. This expression persisted until day 25 of pregnancy and subsequently decreased between days 40-60 as pregnancy progressed. This decrease, together with the truncated form of the receptor, was comparable to that reported in the humans (Licht et al., 2003). We confirmed these results in vitro by demonstrating that decidualization of endometrial stromal cells was associated with a decrease in LHCGR expression (Cameo et al., 2006). The downregulation of receptor levels during pregnancy and in decidual cells coincided with the period of decreased levels of CG in the peripheral serum of pregnant baboons (Fortman et al., 1993). Additionally, we showed that CG was capable of regulating the levels of its own receptor and treatment of decidualized cells with $C G$ restored LHCGR expression (Cameo et al., 2006). Receptor levels in the endometrium however showed a decrease upon treatment with cAMP, as previously shown in gonadal cells in vitro(Menon et al., 2004). Furthermore, rescue of the LHCGR by CG was not possible in the presence of CAMP, indicating a CAMP independent regulation of the LHCGR. Incidentally, CG has also been shown to induce a cAMP- independent pathway in endometrial cells (Srisuparp et al., 2003). Recent studies indicate the regulation of LHCGR expression in the rat ovary by a novel protein, the LHreceptor binding protein, which utilizes a cAMP-dependent path- way to inhibit LHCGR expression (Peegel et al., 2005). Hence, decidualization, which is a cAMP dependent mechanism, may also possibly mediate the regulation of the receptor in this manner. Thus, details of the molecular mechanisms and potential cross-talk between the various regulatory components are far from clear and are open to investigation.

\section{Endometrial responses}

Using the in vivo baboon model (Fazleabas et al., 1999) we clearly elucidated the paracrine effects of CG on the endometrium, which mimicked the early maternal response to pregnancy. In order to elucidate changes in endometrial gene expression with CG, we carried out microarray analysis on whole endometrial samples taken from biopsies of CG- treated and control baboons on day 10 post- ovulation. We identified a set of novel genes that are differentially regulated in animals infused with CG as compared to controls, whose expression levels were verified using real time PCR and the presence of the protein product was confirmed using immunohistochemistry (Sherwin et al., 2006).

Among the genes significantly influenced by $C G$ are the leukemia inhibitory factor (LIF), an interleukin 6 class cytokine, the complement component $\mathrm{C} 3$, the radical scavenging enzyme superoxide dismutase 2 (SOD2), the matrix metalloproteinase 7 (MMP7) and the immunomodulatory compound glycodelin, all of which were up-regulated in response to $\mathrm{CG}$ and the regulator of the Wnt-signaling pathway, soluble frizzled receptor protein 4 which was down-regulated in response to CG treatment.

The importance of LIF and gp130 (the signaling element of the LIF receptor) has been shown in the murine model (Stewart et al., 1992) and in other primates (Yue etal., 2000) as well as in humans (Licht et al., 2001). LIF has been recently shown to regulate extravillous trophoblast adhesion to the extracellular matrix (ECM) suggesting an important role in trophoblast invasion and early placental development (Tapia et al., 2008).

The regulation of $\mathrm{C} 3$ and SOD2 indicates that $C G$ plays a role in regulating the immune system and protection against oxidative damage during pregnancy. In response to CG treatment, C3 was primarily expressed in the stromal compartment and SOD2 in the glandular epithelial compartment of the baboon endometrium in comparison to controls. C3 plays an integral role in triggering the complement pathway to promote phagocytosis, local inflammatory responses and activating the humoral response (Sahu and Lambris, 2001). The up-regulation of SOD2 by CG indicates the role played by $C G$ in regulating oxidative stress during pregnancy.

In addition, CG up-regulated the expression of glycodelin, a protein demonstrated to have immunosuppressive functions (Bolton et al., 1987; Karande et al., 2005). Glycodelin, a progesterone regulated gene is one of the most abundant secretory glycoproteins in the primate endometrium during implantation and early pregnancy (Seppala etal., 2002) and is proposed to play a significant role in protecting the embryo from maternal immune responses. It has been shown inhibit proliferation and induce apoptosis in T cells (Mukhopadhyay et al., 2001). Apart from this, the additional regulation of the endometrial stromal protein, SCP, a potent regulator of T-cells (Tagoh et al., 1996) by CG (Lobo et al., 2001) emphasizes the immune-modulatory role of this embryonic signal.

Metalloproteinases play an important role in remodeling the 
ECM of the endometrium during normal cycle and also during implantation (Goffin et al., 2003). Invasion of the trophoblast into the endometrium requires a delicate balance between tissue degradation and maintenance, regulated by a stromal-epithelial interaction and a balance between ovarian and embryonic hormones. MMP-7, a metalloproteinase shown to be present in the glandular epithelium and known to degrade ECM proteins like proteoglycans, fibronectin, elastin, and casein, has been shown to be suppressed by progesterone in humans thus promoting preservation and cellular differentiation of the endometrium (Osteen et al., 2003). On the other hand, CG up-regulates the expression of MMP-7 in both baboons and humans (Rodgers et al., 1994; Sherwin et al., 2007; Yanaihara et al., 2004), thus being able to overcome the inhibitory effect of progesterone that is seen during the menstrual cycle.

Finally, CG also regulates the members of the Wnt signaling pathway, a vital regulator of embryo implantation, which controls processes including embryogenesis, cell proliferation and differentiation (Xie et al., 2008). CG up-regulated the expression of the Wnt pathway inhibitor Dickopff -1 and down-regulated levels of soluble frizzled receptor protein 4 , indicating its role in maintaining a balance between the members of the Wnt pathway during implantation.

Overall, these studies revealed a direct effect of CG on the uterine endometrium and specifically the ability of CG to modulate genes related to and important for embryo attachment and endometrial remodeling for implantation.

\section{Epithelial responses}

To examine the molecular mechanisms of CG signaling in the endometrial epithelium, we initiated an in vitrostudy using primary baboon endometrial epithelial cells and a human endometrial epithelial cell line, HES (Srisuparp et al., 2003). Mechanisms of LHCGR action include stimulation of multiple signal transduction effector systems, including adenylyl cyclase and the cAMP pathway, one of the classical activator systems of the steroidogenic pathway in gonadal cells (Hirakawa et al., 2002; Parakh et al., 2006). Alternatively LHCGR can work via the induction of inositol phospholipid pathway involving phospholipase- $\mathrm{C}$ and diacylglycerol. Both these conduits lead to activation of the mitogen activated protein kinase (MAPK) pathway in various cell models (Ryu et al., 1998; Steele and Leung, 1992). Our in vitro studies indicated that CG induced a MAPK pathway in endometrial epithelial cells leading to prostaglandin $\mathrm{E}_{2}\left(\mathrm{PGE}_{2}\right)$ production. Prostaglandins have been shown to regulate the initial attachment of the embryo to the epithelium by playing a role in endometrial proliferation, differentiation and vascular permeability (Dey, 2005; Kennedy et al., 2007; Wang and Dey, 2005). The expression of cyclooxygenase-2 (COX-2), the rate limiting step in $\mathrm{PGE}_{2}$ synthesis, has been well characterized in the human (Marions and Danielsson, 1999) and the mouse (Chakraborty et al., 1996; $\mathrm{Ni}$ et al., 2002; $\mathrm{Ni}$ et al., 2003) uterus during pregnancy. In addition, COX-2 induction by CG has been demonstrated in human endometrial glandular epithelial cells (Zhou et al., 1999) and adenocarcinoma cells (Munir et al., 1999; Tsai et al., 2008). COX-2 is also expressed in the epithelium and the decidualizing stroma in the baboon (Kim et al., 1999) and the endometrium of the Rhesus monkey from day 20-25 of the menstrual cycle (Milne et al., 2001; Sun et al., 2004). Murine models have demonstrated that the absence of prostaglandins lead to multiple reproductive failures particularly due to implantation defects (Kennedy et al., 2007; Lim et al., 1997).

The MAPK pathway in the endometrial epithelial cells is activated independent of the classical CAMP/protein kinase A induction since $C G$ failed to induce production of intracellular cAMP in these cells and phosphorylation of the extracellular regulatory kinase occurs independent of inhibitors of protein kinase $A$ (Srisuparp et al., 2003). Preliminary work from our laboratory indicated that this MAPK pathway is activated in a manner distinct from the classical signaling paradigms including activation of the $G_{i}$ subunit or transactivation of the epidermal growth factor receptor and instead was mediated via the activation of the phospho-inositol -3- kinase pathway (Banerjee et al., 2008). Receptor desensitization in the presence of high ligand concentrations involving the termination of the $G_{s}$ mediated classical signaling has been described in gonadal cells (Hunzicker-Dunn and Maizels, 2006). In the presence of the embryo, the uterine endometrium is subjected to high levels of $C G$. It is probable that the endometrium maintains its function and responsiveness to the embryonic signal by silencing the canonical $G_{s}$ and $G_{i}$ pathways and maintaining signaling through the inositol phosphate dependent MAPK pathway. Downstream, this leads to the induction of the microsomal enzyme prostanoid synthase - prostaglandin $\mathrm{E}$ synthase, known to enzymatically convert the COX-2 product $\mathrm{PGH}_{2}$ to $\mathrm{PGE}_{2}$ (Park et al., 2006). Expression of prostaglandin $\mathrm{E}$ synthase has been well characterized in the human endometrium (Milne et al., 2001). Together with our previous data of CG induced $\mathrm{PGE}_{2}$ production in HES cells (Srisuparp et al., 2003) these studies indicate that the activation of a single continuous pathway by CG leads to prostaglandin synthesis in the endometrial epithelium.

\section{Stromal responses}

The primary effect of $C G$ on stromal fibroblasts is the induction of $\alpha$ SMA (Fazleabas et al., 1999). This stimulation has been attributed to a consequence of stromal integrin binding to the secreted ECM proteins (Fazleabas et al., 1997). We reason that the induction of $\alpha \mathrm{SMA}$ by $\mathrm{CG}$ is essential to terminate the proliferative process of the endometrial stromal cells and initiate the differentiation process, which is a key to decidualization (Kim et al., 1999). The differentiation of a stromal fibroblast to a decidualized cell with a secretory phenotype is a pre-requisite for the maintenance of pregnancy in the primate. The baboon endometrium undergoes morphological and secretory changes during pregnancy, associated with the development of a functional placenta and a decidualized endometrium (Fazleabas et al., 1993). Decidual cells play an important role by providing nutritional support to the embryo. A very well characterized marker for decidual cells of the primate uterus is the insulin-like growth factor binding protein (IGFBP-1), which is secreted selectively by decidualized stromal cells (Fazleabas et al., 1989). In both the normal and the simulated pregnant model in the baboon, IGFBP1 expression was clearly shown to be regulated by the conceptus and embryonic signals (Fazleabas et al., 1997; Tarantino et al., 1992). Subsequently, we found that IGFBP-1 expression in vitro in decidualizing fibroblasts requires the presence of ovarian hormones and CAMP (Kim et al., 1998). Differentiation of the stromal fibroblasts to decidual cells is linked intrinsically to reor- 
ganization of the cellular cytoskeleton. IGFBP -1 induction was concurrently associated with a decrease in $\alpha$ SMA expression both in vivo (Christensen et al., 1995) and in vitro (Kim et al., 1998). We also showed that alterations in the cytoskeleton of stromal cells were a prerequisite for their differentiation into the decidualized phenotype and subsequent production of IGFBP-1 (Kim et al., 1999). Disruption of actin filaments in vitro in the presence of ovarian hormones and CG both rescues cells from their apoptotic demise and also differentiates them into the decidualized phenotype (Jasinska etal., 2006). Recently we have also shown that interfering with actin-myosin interactions by the phosphorylation of myosin light chain prevented decidualization of endometrial stromal cells in vitro (Ihnatovych et al., 2007). These studies all point to the importance of the CG induced cytoskeletal regulation as a requisite to the initiation of decidualization.

At the end of each menstrual cycle, the endometrium undergoes regression by the process of apoptosis. The level of apoptosis throughout the menstrual cycle has been documented and increases progressively from the proliferative phase and peaks at menses (Vaskivuo et al., 2000). In the event of conception, the embryonic signal is believed to rescue the endometrium from its apoptotic cascade and direct it to a pattern of differentiation. CG has been shown to play a major role in inhibiting this apoptotic fate of endometrial cells (Lovely et al., 2005). The importance of CG in mediating the prevention of apoptosis is emphasized by the fact that CG was capable of rescuing stromal cells from apoptosis upon treatment with a cytoskeletal disruptor. We further elaborated on the role played by $C G$ in the inhibition of apoptosis by demonstrating the induction of anti-apoptotic genes e.g. Bcl-2, by CG. Lastly, the link between differentiation due to decidualization and inhibition of stromal cell apoptosis was re-affirmed as cells undergoing apoptosis were recued upon treatment with decidualization markers IGFBP-1 and prolactin (Jasinska et al., 2006). We currently propose that the regulation of stromal cell survival and differentiation is mediated by a critical modulator of cell fate, Notch-1 (Afshar et al., 2007). Induction of Notch-1 in stromal fibroblasts in response to $C G$ during the window of uterine receptivity upregulates anti-apoptotic genes and induces $\alpha$ SMA, an important mediator of cellular differentiation. We reason therefore, that CG and Notch-1 cooperatively regulate apoptotic rescue and stromal cell differentiation, which are critical to successful pregnancy.

\section{Clinical application and future perspectives}

Even eighty years following its discovery, the role of CG in clinical and therapeutic applications continues to be underestimated. The midcycle LH surge is critical for normal oocyte maturation and ovulation and LH and CG have been used interchangeably in stimulating events such as induction of folliculogenesis, oocyte maturation and ovulation in clinical procedures (Griesinger et al., 2006). Studies from oocyte donation programs clearly indicated the possible applications of CG on the uterine response, independent of ovarian functions (Filicori et al., 2005). In women undergoing pituitary desensitization and prior preparation of the endometrium with ovarian hormones, endometrial thickness and implantation rates were significantly higher in groups receiving exogenous CG prior to embryo transfer (Tesarik et al., 2003). Additonally, luteal phase support with CG or progesterone following in vitro fertilization increased pregnancy rates (Daya and Gunby, 2004). Low-dose CG has been used to complete controlled ovarian stimulation and the use of $C G$ is associated with a reduced number of small pre-ovulatory follicles, which could thus reduce the risk of ovarian hyperstimulation syndrome (Filicori et al., 2005). In addition, invasion promoting and angiogenic properties of CG are very well documented (Zygmunt et al., 2002) and these correlate with the fact that CG has been associated with increase in the development of fibroids (Baird et al., 2006). Furthermore, CG is of clinical importance for the diagnosis of pregnancy, monitoring of abnormal and ectopic pregnancies, testing for Down's syndrome or monitoring therapy of CG-secreting malignancies (Lottersberger et al., 2003). However, administration of antisense chorionic gonadotropin beta gene into choriocarcinoma cells also suppressed the cell proliferation and induced apoptosis (Hamada et al., 2005). Interestingly, administration of a combination of ovarian hormones and CG to virgin animals either before or after carcinogen exposure also confers strong and lasting protection against tumor development (Guzman et al., 1999). Possible long-term protective association for breast cancer risk with elevated levels of circulating CG in the early stages of pregnancy has been reported. Women with high CG levels tended to be at lower risk of breast cancer than those with low levels (Lukanova et al., 2008). A possibility of regulation of myometrial contractivity by $\mathrm{CG}$ and hence a mechanism to prevent pre-term labor has also been suggested (Ticconi et al., 2006).

Thus, the early signal from the embryo, CG presents itself as a versatile molecule altering ovarian, endometrial and trophoblastic functions and mediating multiple events related to endometrial receptivity and embryo implantation. Development of molecular techniques and models to study embryonic and endometrial changes during implantation is extremely important to increase implantation rates in assisted reproductive therapies and consequently improve birth rates and fecundity.

\section{Acknowledgements}

The majority of the studies from our laboratory summarized in this review were supported by NIH grants HD 29964, HD 36759 and HD 42280 to $A T F$.

\section{References}

AFSHAR, Y., STANCULESCU, A., MIELE, L. and FAZLEABAS, A. T. (2007). The role of chorionic gonadotropin and Notch1 in implantation. $J$ Assist Reprod Genet 24: 296-302.

APAJA, P. M., AATSINKI, J. T., RAJANIEMI, H. J. and PETAJA-REPO, U. E. (2005). Expression of the mature luteinizing hormone receptor in rodent urogenital and adrenal tissues is developmentally regulated at a posttranslational level. Endocrinology 146: 3224-3232.

ASCHHEIM, S. and ZONDEK, B. (1928). Die Schwangerschaft diagnose aus dem Harn durch Nachweis des Hypophysenvorderlappenhormons. Klinische Wochenschrift 7: 1404.

BAHL, O. P. (1969). Human chorionic gonadotropin. I. Purification and physicochemical properties. J Biol Chem 244: 567-574.

BAIRD, D. D., KESNER, J. S. and DUNSON, D. B. (2006). Luteinizing hormone in premenopausal women may stimulate uterine leiomyomata development. JSOC Gynecol Investig 13: 130-135.

BANASZAK, S., BRUDNEY, A., DONNELLY, K., CHAI, D., CHWALISZ, K. and FAZLEABAS, A. T. (2000). Modulation of the action of chorionic gonadotropin 
in the baboon (Papio anubis) uterus by a progesterone receptor antagonist (ZK 137. 316). Biol Reprod 63: 820-825.

BANERJEE, P., SAPRU, K., STRAKOVA, Z. and FAZLEABAS, A. (2009). Chorionic gonadotropin regulates prostaglandin $E$ synthase via a phosphatidylinositol 3-kinase-extracellular regulatory kinase pathway in a human endometrial epithelial cell line: implications for endometrial responses for embryo implantation. Endocrinology 150: 4326-4337.

BASS, K. E., MORRISH, D., ROTH, I., BHARDWAJ, D., TAYLOR, R., ZHOU, Y. and FISHER, S. J. (1994). Human cytotrophoblast invasion is up-regulated by epidermal growth factor: evidence that paracrine factors modify this process. Dev Bio/ 164: 550-561.

BO, M. and BOIME, I. (1992). Identification of the transcriptionally active genes of the chorionic gonadotropin beta gene cluster in vivo. J Biol Chem 267: 31793184.

BOLTON, A. E., POCKLEY, A. G., CLOUGH, K. J., MOWLES, E. A., STOKER, R. J., WESTWOOD, O. M. and CHAPMAN, M. G. (1987). Identification of placental protein 14 as an immunosuppressive factor in human reproduction. Lancet 1 : 593-595.

BONDUELLE, M. L., DODD, R., LIEBAERS, I., VAN STEIRTEGHEM, A., WILLIAMSON, R. and AKHURST, R. (1988). Chorionic gonadotrophin-beta mRNA, a trophoblast marker, is expressed in human 8-cell embryos derived from tripronucleate zygotes. Hum Reprod 3: 909-914.

CAMEO, P., SRISUPARP, S., STRAKOVA, Z. and FAZLEABAS, A. T. (2004). Chorionic gonadotropin and uterine dialogue in the primate. Reprod Biol Endocrino/2: 50.

CAMEO, P., SZMIDT, M., STRAKOVA, Z., MAVROGIANIS, P., SHARPE-TIMMS, K. L. and FAZLEABAS, A. T. (2006). Decidualization Regulates the Expression of the Endometrial Chorionic Gonadotrophin Receptor in the Primate. Biol Reprod 75: 681-689.

CHAKRABORTY, I., DAS, S. K., WANG, J. and DEY, S. K. (1996). Developmental expression of the cyclo-oxygenase-1 and cyclo-oxygenase-2 genes in the periimplantation mouse uterus and their differential regulation by the blastocyst and ovarian steroids. J Mol Endocrinol 16: 107-122.

CHRISTENSEN, S., VERHAGE, H. G., NOWAK, G., DE LANEROLLE, P., FLEMING, S., BELL, S. C., FAZLEABAS, A. T. and HILD-PETITO, S. (1995). Smooth muscle myosin II and alpha smooth muscle actin expression in the baboon (Papio anubis) uterus is associated with glandular secretory activity and stromal cell transformation. Biol Reprod53: 598-608.

DAKOUR, J., LI, H., CHEN, H. and MORRISH, D. W. (1999). EGF promotes development of a differentiated trophoblast phenotype having c-myc and junB proto-oncogene activation. Placenta 20: 119-126.

DAYA, S. and GUNBY, J. (2004). Luteal phase support in assisted reproduction cycles. Cochrane Database Syst Rev. CD004830.

DEY, S. K. (2005). Reproductive biology: fatty link to fertility. Nature 435: 34-35.

FAZLEABAS, A. T., DONNELLY, K. M., HILD-PETITO, S., HAUSERMANN, H. M. and VERHAGE, H. G. (1997). Secretory proteins of the baboon (Papio anubis) endometrium: regulation during the menstrual cycle and early pregnancy. Hum Reprod Update 3: 553-559.

FAZLEABAS, A. T., VERHAGE, H. G., WAITES, G. and BELL, S. C. (1989). Characterization of an insulin-like growth factor binding protein, analogous to human pregnancy-associated secreted endometrial alpha 1-globulin, in decidua of the baboon (Papio anubis) placenta. Biol Reprod 40: 873-885.

FAZLEABAS, A. T., DONNELLY, K. M., MAVROGIANIS, P. A. and VERHAGE, H. G. (1993). Secretory and morphological changes in the baboon (Papio anubis) uterus and placenta during early pregnancy. Biol Reprod 49: 695-704.

FAZLEABAS, A. T., BELL, S. C., FLEMING, S., SUN, J. and LESSEY, B. A. (1997). Distribution of integrins and the extracellular matrix proteins in the baboon endometrium during the menstrual cycle and early pregnancy. Biol Reprod56: 348-356.

FAZLEABAS, A. T., DONNELLY, K. M., SRINIVASAN, S., FORTMAN, J. D. and MILLER, J. B. (1999). Modulation of the baboon (Papio anubis) uterine endometrium by chorionic gonadotrophin during the period of uterine receptivity. Proc Natl Acad Sci USA 96: 2543-2548.

FAZLEABAS, A. T., KIM, J. J. and STRAKOVA, Z. (2004). Implantation: embryonic signals and the modulation of the uterine environment-a review. Placenta 25 Suppl A: S26-S31.
FILICORI, M., FAZLEABAS, A. T., HUHTANIEMI, I., LICHT, P., RAO CH, V., TESARIK, J. and ZYGMUNT, M. (2005). Novel concepts of human chorionic gonadotropin: reproductive system interactions and potential in the management of infertility. Fertil Steril 84: 275-284.

FORTMAN, J. D., HERRING, J. M., MILLER, J. B., HESS, D. L., VERHAGE, H. G. and FAZLEABAS, A. T. (1993). Chorionic gonadotropin, estradiol, and progesterone levels in baboons (Papio anubis) during early pregnancy and spontaneous abortion. Biol Reprod 49: 737-742.

GOFFIN, F., MUNAUt, C., FRANKENNE, F., PERRIER D'HAUTERIVE, S., BELIARD, A., FRIDMAN, V., NERVO, P., COLIGE, A. and FOIDART, J. M. (2003). Expression pattern of metalloproteinases and tissue inhibitors of matrixmetalloproteinases in cycling human endometrium. Biol Reprod69: 976-984.

GRIESINGER, G., DIEDRICH, K., DEVROEY, P. and KOLIBIANAKIS, E. M. (2006). GnRH agonist for triggering final oocyte maturation in the $\mathrm{GnRH}$ antagonist ovarian hyperstimulation protocol: a systematic review and metaanalysis. Hum Reprod Update 12: 159-168.

GUZMAN, R. C., YANG, J., RAJKUMAR, L., THORDARSON, G., CHEN, X. and NANDI, S. (1999). Hormonal prevention of breast cancer: mimicking the protective effect of pregnancy. Proc Natl Acad Sci USA 96: 2520-2525.

HAMADA, A. L., NAKABAYASHI, K., SATO, A., KIYOSHI, K., TAKAMATSU, Y., LAOAG-FERNANDEZ, J. B., OHARA, N. and MARUO, T. (2005). Transfection of antisense chorionic gonadotropin beta gene into choriocarcinoma cells suppresses the cell proliferation and induces apoptosis. J Clin Endocrinol Metab 90: 4873-4879.

HILD-PETITO, S., FAZLEABAS, A. T., JULIAN, J. and CARSON, D. D. (1996). Mucin (Muc-1) expression is differentially regulated in uterine luminal and glandular epithelia of the baboon (Papio anubis). Biol Reprod 54: 939-947.

HIRAKAWA, T., GALET, C. and ASCOLI, M. (2002). MA-10 cells transfected with the human lutropin/choriogonadotropin receptor (hLHR): a novel experimental paradigm to study the functional properties of the hLHR. Endocrinology 143 1026-1035.

HUNZICKER-DUNN, M. and MAIZELS, E. T. (2006). FSH signaling pathways in immature granulosa cells that regulate target gene expression: branching out from protein kinase A. Cel/ Signal 18: 1351-1359.

IHNATOVYCH, I., HU, W., MARTIN, J. L., FAZLEABAS, A. T., DE LANEROLLE, P. and STRAKOVA, Z. (2007). Increased phosphorylation of myosin light chain prevents in vitro decidualization. Endocrinology 148: 3176-3184.

JASINSKA, A., STRAKOVA, Z., SZMIDT, M. and FAZLEABAS, A. T. (2006) Human chorionic gonadotropin and decidualization in vitro inhibits cytochalasin-D-induced apoptosis in cultured endometrial stromal fibroblasts. Endocrinology 147: 4112-4121.

KARANDE, A. A., MUKHOPADHYAY, D., JAYACHANDRAN, R., SUNDARRAJ, S. and ALOK, A. (2005). Mechanism of the immunomodulatory activity of glycodelin. Indian J Physiol Pharmaco/49: 271-283.

KENNEDY, T. G., GILLIO-MEINA, C. and PHANG, S. H. (2007). Prostaglandins and the initiation of blastocyst implantation and decidualization. Reproduction 134: 635-643.

KIM, J. J., WANG, J., BAMBRA, C., DAS, S. K., DEY, S. K. and FAZLEABAS, A. T. (1999). Expression of cyclooxygenase-1 and -2 in the baboon endometrium during the menstrual cycle and pregnancy. Endocrinology 140: 2672-2678.

KIM, J. J., JAFFE, R. C. and FAZLEABAS, A. T. (1999). Insulin-like growth factor binding protein-1 expression in baboon endometrial stromal cells: regulation by filamentous actin and requirement for de novo protein synthesis. Endocrinology 140: 997-1004.

KIM, J. J., JAFFE, R. C. and FAZLEABAS, A. T. (1998). Comparative studies on the in vitro decidualization process in the baboon (Papio anubis) and human. Biol Reprod59: 160-168.

LICHT, P., RUSSU, V., LEHMEYER, S. and WILDT, L. (2001). Molecular aspects of direct $\mathrm{LH} / \mathrm{hCG}$ effects on human endometrium-lessons from intrauterine microdialysis in the human female in vivo. Reprod Bio/1: 10-19.

LICHT, P., VON WOLFF, M., BERKHOLZ, A. and WILDT, L. (2003). Evidence for cycle-dependent expression of full-length human chorionic gonadotropin/luteinizing hormone receptor mRNA in human endometrium and decidua. Fertil Steril 79 Suppl 1: 718-723.

LIM, H., PARIA, B. C., DAS, S. K., DINCHUK, J. E., LANGENBACH, R., TRZASKOS, J. M. and DEY, S. K. (1997). Multiple female reproductive failures in 
cyclooxygenase 2-deficient mice. Ce//91: 197-208.

LOBO, S. C., SRISUPARP, S., PENG, X. and FAZLEABAS, A. T. (2001). Uterine receptivity in the baboon: modulation by chorionic gonadotropin. Semin Reprod Med 19: 69-74.

LOHSTROH, P. N., OVERSTREET, J. W., STEWART, D. R., NAKAJIMA, S. T., CRAGUN, J. R., BOYERS, S. P. and LASLEY, B. L. (2005). Secretion and excretion of human chorionic gonadotropin during early pregnancy. Fertil Steril 83: 1000-1011.

LOTTERSBERGER, C., HOERMANN, R., MANN, K., SCHWARZ, S. and BERGER, P. (2003). Tumor- and pregnancy-derived isoforms of human chorionic gonadotropin: biological and diagnostic relevance. Horm Res 59: 125-134.

LOVELY, L. P., FAZLEABAS, A. T., FRITZ, M. A., MCADAMS, D. G. and LESSEY, B. A. (2005). Prevention of endometrial apoptosis: randomized prospective comparison of human chorionic gonadotropin versus progesterone treatment in the luteal phase. J Clin Endocrinol Metab 90: 2351-2356.

LUKANOVA, A., ANDERSSON, R., WULFF, M., ZELENIUCH-JACQUOTTE, A., GRANKVIST, K., DOSSUS, L., AFANASYEVA, Y., JOHANSSON, R., ARSLAN, A. A., LENNER, P., WADELL, G., HALLMANS, G., TONIOLO, P. and LUNDIN, E. (2008). Human Chorionic Gonadotropin and Alpha-Fetoprotein Concentrations in Pregnancy and Maternal Risk of Breast Cancer: A Nested Case-Control Study. Am J Epidemio/168: 1284-1291.

MARGALIOTH, E. J., BEN-CHETRIT, A., GAL, M. and ELDAR-GEVA, T. (2006). Investigation and treatment of repeated implantation failure following IVF-ET. Hum Reprod 21: 3036-3043.

MARIONS, L. and DANIELSSON, K. G. (1999). Expression of cyclo-oxygenase in human endometrium during the implantation period. Mol Hum Reprod5: 961965.

MCFARLAND, K. C., SPRENGEL, R., PHILLIPS, H.S., KOHLER, M., ROSEMBLIT, N., NIKOLICS, K., SEGALOFF, D. L. and SEEBURG, P. H. (1989). Lutropinchoriogonadotropin receptor: an unusual member of the $G$ protein-coupled receptor family. Science 245: 494-499.

MENON, K. M., MUNSHI, U. M., CLOUSER, C. L. and NAIR, A. K. (2004). Regulation of luteinizing hormone/human chorionic gonadotropin receptor expression: a perspective. Biol Reprod 70: 861-866

MILNE, S. A., PERCHICK, G. B., BODDY, S. C. and JABBOUR, H. N. (2001). Expression, localization, and signaling of PGE(2) and EP2/EP4 receptors in human nonpregnant endometrium across the menstrual cycle. JClin Endocrino/ Metab 86: 4453-4459.

MUKHOPADHYAY, D., SUNDERESHAN, S., RAO, C. and KARANDE, A. A (2001). Placental protein 14 induces apoptosis in T cells but not in monocytes. $J$ Biol Chem 276: 28268-28273.

MUNIR, I., FUKUNAGA, K., MIYAZAKI, K., OKAMURA, H. and MIYAMOTO, E. (1999). Mitogen-activated protein kinase activation and regulation of cyclooxygenase 2 expression by platelet-activating factor and hCG in human endometrial adenocarcinoma cell line HEC-1B. J Reprod Fertil 117: 49-59.

MUYAN, M. and BOIME, I. (1997). Secretion of chorionic gonadotropin from human trophoblasts. Placenta 18: 237-241.

NI, H., SUN, T., DING, N. Z., MA, X. H. and YANG, Z. M. (2002). Differential expression of microsomal prostaglandin e synthase at implantation sites and in decidual cells of mouse uterus. Biol Reprod 67: 351-358.

NI, H., SUN, T., MA, X. H. and YANG, Z. M. (2003). Expression and regulation of cytosolic prostaglandin $E$ synthase in mouse uterus during the peri-implantation period. Biol Reprod 68: 744-750.

OSTEEN, K. G., IGARASHI, T. M. and BRUNER-TRAN, K. L. (2003). Progesterone action in the human endometrium: induction of a unique tissue environment which limits matrix metalloproteinase (MMP) expression. Front Biosci 8: d7886.

PAKARAINEN, T., AHTIAINEN, P., ZHANG, F. P., RULLI, S., POUTANEN, M. and HUHTANIEMI, I. (2007). Extragonadal LH/hCG action-not yet time to rewrite textbooks. Molec. Cell Endocrinol. 269: 9-16.

PARAKH, T. N., HERNANDEZ, J. A., GRAMMER, J. C., WECK, J., HUNZICKERDUNN, M., ZELEZNIK, A. J. and NILSON, J. H. (2006). Follicle-stimulating hormone/cAMP regulation of aromatase gene expression requires beta-catenin. Proc Nat/ Acad Sci USA 103: 12435-12440.

PARK, J. Y., PILLINGER, M. H. and ABRAMSON, S. B. (2006). Prostaglandin E2 synthesis and secretion: the role of PGE2 synthases. Clin Immuno/119: 229-
240.

PEEGEL, H., TOWNS, R., NAIR, A. and MENON, K. M. (2005). A novel mechanism for the modulation of luteinizing hormone receptor mRNA expression in the rat ovary. Mol Cell Endocrinol 233: 65-72.

PIERCE, J. G. and PARSONS, T. F. (1981). Glycoprotein hormones: structure and function. Annu Rev Biochem 50: 465-495.

RESHEF, E., LEI, Z. M., RAO, C. V., PRIDHAM, D. D., CHEGINI, N. and LUBORSKY, J. L. (1990). The presence of gonadotropin receptors in nonpregnant human uterus, human placenta, fetal membranes, and decidua. J Clin Endocrinol Metab 70: 421-430.

RODGERS, W. H., MATRISIAN, L. M., GIUDICE, L. C., DSUPIN, B., CANNON, P., SVITEK, C., GORSTEIN, F. and OSTEEN, K. G. (1994). Patterns of matrix metalloproteinase expression in cycling endometrium imply differential functions and regulation by steroid hormones. J Clin Invest 94: 946-953.

RYU, K. S., GILCHRIST, R. L., KOO, Y. B., JI, I. and JI, T. H. (1998). Gene, interaction, signal generation, signal divergence and signal transduction of the LH/CG receptor. Int J Gynaecol Obstet 60 Suppl 1: S9-S20.

SAHU, A. and LAMBRIS, J. D. (2001). Structure and biology of complement protein $\mathrm{C} 3$, a connecting link between innate and acquired immunity. Immuno/ Rev 180 : 35-48.

SEGALOFF, D. L. and ASCOLI, M. (1993). The lutropin/choriogonadotropin receptor.. 4 years later. Endocr Rev 14: 324-347.

SEPPALA, M., TAYLOR, R. N., KOISTINEN, H., KOISTINEN, R. and MILGROM, E. (2002). Glycodelin: a major lipocalin protein of the reproductive axis with diverse actions in cell recognition and differentiation. Endocr Rev23: 401-430.

SHERWIN, J. R., SHARKEY, A., CAMEO, P., CATALANO, R., EDASSERY, S. and FAZLEABAS, A. (2006). Identification of novel genes regulated by chorionic gonadotropin in the baboon endometrium. Endocrinology 148: 618-626.

SHERWIN, J. R., SHARKEY, A. M., CAMEO, P., MAVROGIANIS, P. M., CATALANO, R. D., EDASSERY, S. and FAZLEABAS, A. T. (2007). Identification of Novel Genes Regulated by Chorionic Gonadotropin in Baboon Endometrium during the Window of Implantation. Endocrinology 148: 618-626.

SHI, Q. J., LEI, Z. M., RAO, C. V. and LIN, J. (1993). Novel role of human chorionic gonadotropin in differentiation of human cytotrophoblasts. Endocrinology 132 1387-1395.

SIMON, C., MERCADER, A., GIMENO, M. J. and PELLICER, A. (1997). The interleukin-1 system and human implantation. Am J Reprod Immuno/37: 64-72.

SRISUPARP, S., STRAKOVA, Z., BRUDNEY, A., MUKHERJEE, S., REIERSTAD, S., HUNZICKER-DUNN, M. and FAZLEABAS, A. T. (2003). Signal transduction pathways activated by chorionic gonadotropin in the primate endometrial epithelial cells. Biol Reprod68: 457-464.

STEELE, G. L. and LEUNG, P. C. (1992). Intragonadal signalling mechanisms in the control of steroid hormone production. J Steroid Biochem Mol Bio/41: 515 522.

STEWART, C. L., KASPAR, P., BRUNET, L. J., BHATT, H., GADI, I., KONTGEN, F. and ABBONDANZO, S. J. (1992). Blastocyst implantation depends on maternal expression of leukaemia inhibitory factor. Nature 359: 76-79.

STRAKOVA, Z., SRISUPARP, S. and FAZLEABAS, A. T. (2000). Interleukin-1 beta induces the expression of insulin-like growth factor binding protein-1 during decidualization in the primate. Endocrinology 141: 4664-4670.

STRAKOVA, Z., MAVROGIANIS, P., MENG, X., HASTINGS, J. M., JACKSON, K. S., CAMEO, P., BRUDNEY, A., KNIGHT, O. and FAZLEABAS, A. T. (2005). In vivo infusion of interleukin-1 beta and chorionic gonadotropin induces endometrial changes that mimic early pregnancy events in the baboon. Endocrinology 146: 4097-4104

SUN, T., LI, S. J., DIAO, H. L., TENG, C. B., WANG, H. B. and YANG, Z. M. (2004) Cyclooxygenases and prostaglandin $E$ synthases in the endometrium of the rhesus monkey during the menstrual cycle. Reproduction 127: 465-473.

TAGOH, H., KISHI, H. and MURAGUCHI, A. (1996). Molecular cloning and characterization of a novel stromal cell-derived cDNA encoding a protein that facilitates gene activation of recombination activating gene (RAG)- 1 in human lymphoid progenitors. Biochemi Biophys Res Commun 221: 744-749.

TAPIA, A., SALAMONSEN, L. A., MANUELPILLAI, U. and DIMITRIADIS, E. (2008) Leukemia inhibitory factor promotes human first trimester extravillous trophoblast adhesion to extracellular matrix and secretion of tissue inhibitor of metalloproteinases-1 and -2. Hum Reprod 23: 1724-1732. 
TARANTINO, S., VERHAGE, H. G. and FAZLEABAS, A. T. (1992). Regulation of insulin-like growth factor-binding proteins in the baboon (Papio anubis) uterus during early pregnancy. Endocrinology 130: 2354-2362.

TARARA, R., ENDERS, A. C., HENDRICKX, A. G., GULAMHUSEIN, N., HODGES, J. K., HEARN, J. P., ELEY, R. B. and ELSE, J. G. (1987). Early implantation and embryonic development of the baboon: stages 5, 6 and 7. Anat Embryol176: 267-275.

TESARIK, J., HAZOUT, A. and MENDOZA, C. (2003). Luteinizing hormone affects uterine receptivity independently of ovarian function. Reprod Biomed Online 7: 59-64.

TICCONI, C., BELMONTE, A., PICCIONE, E. and RAO, C. H. (2006). Fetoplacental communication system with the myometrium inpregnancy and parturition: the role of hormones, neurohormones, inflammatory mediators, and locally active factors. J Matern Fetal Neonatal Med 19: 125-133.

TSAI, E. M., CHAN, T. F., CHEN, Y. H., HSU, S. C., CHUANG, C. Y. and LEE, J. N. (2008). Mifepristone attenuates human chorionic gonadotropin-induced extracellular signal-regulated kinase 1/2 phosphorylation, cyclooxygenase-2, and prostaglandin E2 production in human granulosa luteal cells. Fertil Steril 89: 1522-1529.

VASKIVUO, T. E., STENBACK, F., KARHUMAA, P., RISTELI, J., DUNKEL, L. and TAPANAINEN, J. S. (2000). Apoptosis and apoptosis-related proteins in human endometrium. Mol Cell Endocrinol 165: 75-83.

VIGANO, P., MANGIONI, S., POMPEI, F. and CHIODO, I. (2003). Maternalconceptus cross talk-a review. Placenta 24 Suppl B: S56-S61.

WANG, H. and DEY, S. K. (2005). Lipid signaling in embryo implantation. Prostag- landins Other Lipid Mediat 77: 84-102.

WILCOX, A. J., BAIRD, D. D. and WEINBERG, C. R. (1999). Time of implantation of the conceptus and loss of pregnancy. NEng/J Med340: 1796-1799.

XIE, H., TRANGUCH, S., JIA, X., ZHANG, H., DAS, S. K., DEY, S. K., KUO, C. J. and WANG, H. (2008). Inactivation of nuclear Wnt-beta-catenin signaling limits blastocyst competency for implantation. Development 135: 717-727.

YANAIHARA, A., OTSUKA, Y., IWASAKI, S., KOIDE, K., AIDA, T. and OKAI, T. (2004). Comparison in gene expression of secretory human endometrium using laser microdissection. Reprod Biol Endocrino/2: 66.

YUE, Z. P., YANG, Z. M., WEI, P., LI, S. J., WANG, H. B., TAN, J. H. and HARPER, M. J. (2000). Leukemia inhibitory factor, leukemia inhibitory factor receptor, and glycoprotein 130 in rhesus monkey uterus during menstrual cycle and early pregnancy. Biol Reprod63: 508-512.

ZHOU, X. L., LEI, Z. M. and RAO, C. V. (1999). Treatment of human endometrial gland epithelial cells with chorionic gonadotropin/luteinizing hormone increases the expression of the cyclooxygenase-2 gene. J Clin Endocrinol Metab 84: 3364-3377.

ZYGMUNT, M., MCKINNON, T., HERR, F., LALA, P. K. and HAN, V. K. (2005). HCG increases trophoblast migration in vitro via the insulin-like growth factor-II/ mannose-6 phosphate receptor. Mol Hum Reprod 11: 261-267.

ZYGMUNT, M., HERR, F., KELLER-SCHOENWETTER, S., KUNZI-RAPP, K., MUNSTEDT, K., RAO, C. V., LANG, U. and PREISSNER, K. T. (2002). Characterization of human chorionic gonadotropin as a novel angiogenic factor. J Clin Endocrinol Metab 87: 5290-5296. 


\section{Further Related Reading, published previously in the Int. J. Dev. Biol.}

See our recent Special Issue Epigenetics \& Development edited by Saadi Khochbin and Stefan Nonchev at: http://www.ijdb.ehu.es/web/contents.php?vol=53\&issue=2-3

See Special Issue Pattern Formation edited by Michael K. Richardson and Cheng-Ming Chuong at: http://www.ijdb.ehu.es/web/contents.php?vol=53\&issue=5-6

Local regulation of implantation at the human fetal-maternal interface

Evdokia Dimitriadis, Guiying Nie, Natalie J. Hannan, Premila Paiva and Lois A. Salamonsen Int. J. Dev. Biol. (2010) 54: 313-322 (doi: 10.1387/ijdb.082772ed)

On the role of placental Major Histocompatibility Complex and decidual leukocytes in implantation and pregnancy success using non-human primate models

Thaddeus G. Golos, Gennadiy I. Bondarenko, Svetlana V. Dambaeva, Edith E. Breburda, and Maureen Durning

Int. J. Dev. Biol. (2010) 54: 431-443 (doi: 10.1387/ijdb.082797tg)

Implantation: molecular basis of embryo-uterine dialogue.

B.C. Paria, H. Song and S.K. Dey

Int. J. Dev. Biol. (2001) 45: 597-605

Expression pattern of different gap junction connexins is related to embryo Implantation. R Grümmer, B Reuss and $\mathrm{E}$ Winterhager

Int. J. Dev. Biol. (1996) 40: 361-367

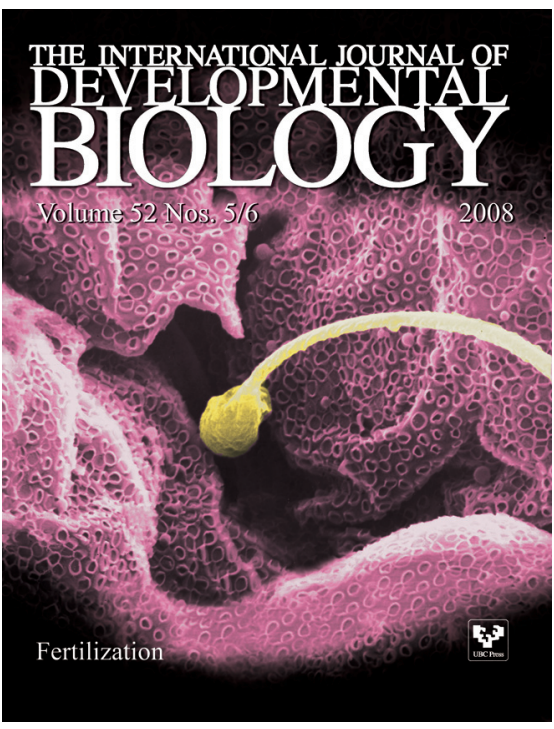

Epithelial cell polarity and embryo implantation in mammals.

M. Thie, P. Fuchs and H.W. Denker

Int. J. Dev. Biol. (1996) 40: 389-393

5 yr ISI Impact Factor $(2008)=3.271$
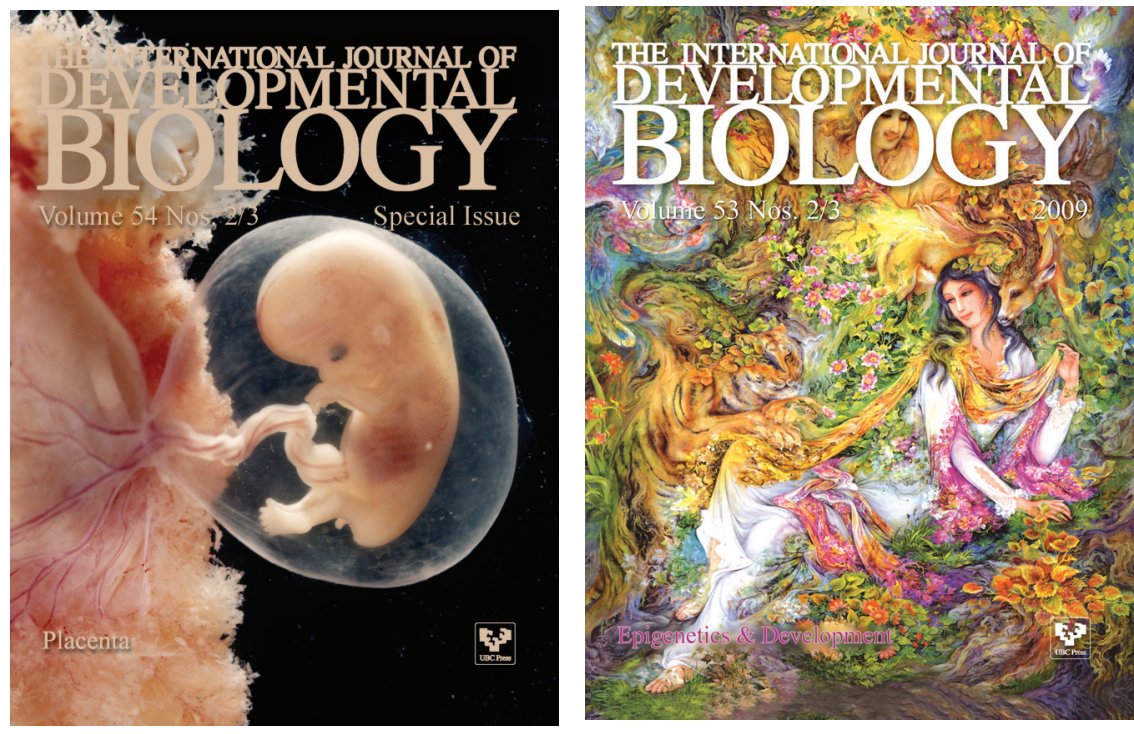